\title{
INTERSTOCK EFFECT ON THE GROWTH OF MANDARIN CV BATU 55, TANGERINE CV PONTIANAK AND LIME CV NIMAS PROPAGATED BY GRAFTING
}

\author{
Sugiyatno Agus*, Palupi Norry Eka \\ Indonesian Citrus and Subtropical Fruits Research Institute, Indonesia \\ *E-mail: agus.sugiyatno@gmail.com
}

\begin{abstract}
Japansche citroen (JC) rootstock is still the main choice for producing citrus seeds for its high availability and compatibility. Other rootstocks have been used in the production, yet they produce unsatisfying results. Based on the theory, there is an alternative to use rootstock as interstock in order to stimulate the growth of scion. The objective of this reseach is to understand the effect of interstock on the growth of Mandarin cv. Batu 55, Tangerine cv. Pontianak and Lime cv. Nimas. This research was conducted in the screen house of Tlekung Experimental Field of Indonesian Citrus and Subtropical Fruits Research Institute (ICSFRI) in Batu-East Java, located on $950 \mathrm{~m}$ asl, from January to April 2016. This research was arranged in a CRD design with 4 replications and 24 interstock-scion combination treatments. The interstocks used in this study were Carizzo citrange, Citrumello, Poncirus trifoliata, Volkameriana, Rough lemon, Troyer citrange, Kanci and control (JC) combined with 3 scions namely Mandarin cv. Batu 55, Tangerine cv. Pontianak and Lime cv. Nimas propagated by grafting. The result showed the percentage of successful grafting ranged between $37.5 \%$ to $100 \%$, while the percentage of the shoot formed on grafted plants was $75 \%-100 \%$. The use of Poncirus trifoliata as interstock has stimulated fastest bud break on Tangerine cv. Pontianak in just 24.75 days while the Troyer citrange has stimulated better shoot growth in Lime cv. Nimas, resulted to the highest shoot around $52.20 \mathrm{~cm}$ which was significantly different from other treatments. Meanwhile, Carizzo citrange has been found to have some influences to the plant diameter and the number of leave of Lime cv. Nimas but showed insignificant effect on the growth of its own diameter. The use of interstock showed that it can be used to promote the growth of scion which usually has slow growth when it is directly grafted on the rootstock.
\end{abstract}

\section{KEY WORDS}

Citrus, rootstock, interstock, grafting.

Propagation of citrus plants in Indonesia is generally performed by grafting method using rootstock and certain type of scion. The widely used rootstock by nursery and citrus growers are the Japansche citroen (JC) and small amount of Rough lemon (RL). Rootstock $\mathrm{JC}$ is more preferable since it has high adaptability and compatibility with any types of citrus in Indonesia, besides it is also resistant to drought and salinity. However, it is susceptible to diseases such as CVPD, CTV, CEV, root and stem rot (Supriyanto and Setiono, 2006). Since it is widely used, this rootstock is available in various regions in Indonesia such as East Java, Central Java, Bali, Sulawesi and Sumatra (Sugiyatno et al. 2013).

In Indonesia, a number of research related the use of rootstock for marginal land have been conducted related to various responses of the scions (Supriyanto and Setiono, 2006; Supriyanto and Setiono, 2008). Other rootstocks such as Poncirus Trifoliata, Troyer Citrange, Carizzo Citrange, Cleopatra Mandarin, Volkameriana, Citrumello and Flying Dragon have been introduced to nursery and citrus growers and their adaptabilities are being evaluated (Hardiyanto et al. 2010). Outside Indonesia, the use of tetraploid citrus rootstock such as Carrizo, Troyer' Citranges, Swingle Citrumelo, Trifoliates Davis A and Flying Dragon have been reported to stimulate higher yield in irrigated field of Tahiti Lime (Nunez et al. 2011).

In some cases, the potency of scion does not appear when it is grafted onto certain type of rootstock which show signs of incompatibility. However, its potency will appear when the rootstock is being used as an interstock. The length of interstock has no obvious effect 
on the content of micro elements but it has significant impact on the content of Mn on citrus leaves of 'Kutdiken' Lemon compared to 'Star Ruby' grapefruit (Yilmaz et al. 2014). Insertion of interstock between rootstock and scion could improve growth, extend the plant life, increase productivity and quality, and also increase its tolerance to salinity (Aboutalebi and Hasanzadeh, 2014)

Other research on the use of interstock have proven that it could prolong life and improve the quality and production of lemon (Izquierdo et al. 2004). Vegetative growth and fruit production are influenced by the type of rootstock used when Flying dragon is used as interstock. In the rootstock Catania 2 Volkamer lemon, Flying dragon interstock reduced the size of the plant, while in Davis A trifoliate rootstock, Flying dragon interstock increased the size of the plant (Nunez et al. 2011). Citrumello interstock has the potential to encourage vegetative growth of the plants; Rangpur lime, Flying dragon and Troyer rootstocks potentially control the growth of plants, while Flying dragon interstock potentially stimulates flowering and fruiting in Pumello cv. Nambangan (Susanto et al. 2010). The combination of interstock Citrus grandis with rootstock Citrus hystrix and Citrus hystrix interstock with Citrus grandis rootstock could prevent the transmission of HLB disease on scion from occurring (Shokrollah et al. 2011).

The use of interstock is expected to provide solutions toward some problems such as the slow growth of plants and the low grafting success of certain scion. In Indonesia, research on the use of interstock has not been widely documented. For that purpose, this research was conducted in order to determine the effect of using various interstocks on the plant growth of Mandarin cv. Batu 55, Tangerine cv. Pontianak and Lime cv. Nimas.

\section{MATERIALS AND METHODS OF RESEARCH}

This study was conducted at the Tlekung Experimental Field, Indonesian Citrus and Subtropical Fruit Research Institute (Balitjestro), Batu - East Java with altitude of $950 \mathrm{~m}$ from January to May 2016. The study was done based on completely randomized design (CRD), with 4 times repetition and 24 combinations of treatments as follows:

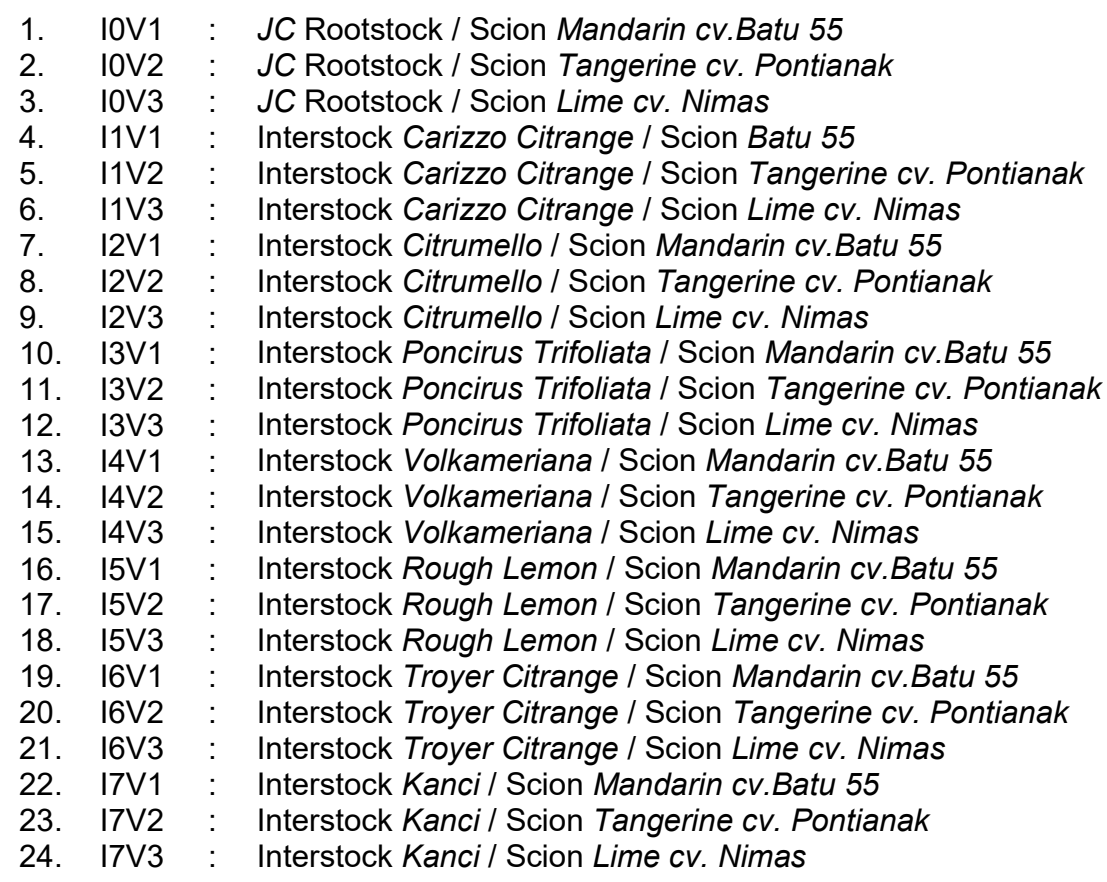

Procedure. Eight month old of interstock plants including Carizzo citrange, Citrumello, Poncirus trifoliata, Volkameriana, Rough lemon, Troyer citrange, Kanci and Japansche citroen were optimally cultivated in polybag. A month prior to the grafting, interstock plants 
were fertilized with $\mathrm{N}$ to achieve active growth since in this phase, grafting is easier to do and it offers high rate of success.

Disease free budwoods of scions were taken from Budwood Multiplication Block based on the disease free citrus seed production and distribution standard that has been imposed by the government. Scions of Mandarin cv Batu 55 were taken from Tlekung Experimental Field while Tangerine cv Pontianak and Lime cv Nimas scions were taken from Punten Experimental Field. Grafting was conducted in the screen house in the morning, at the temperature of around $25^{\circ} \mathrm{C}$ and $70 \%$ relative humidity. The plant maintenance was done based on the recommendation of citrus seed maintainance.
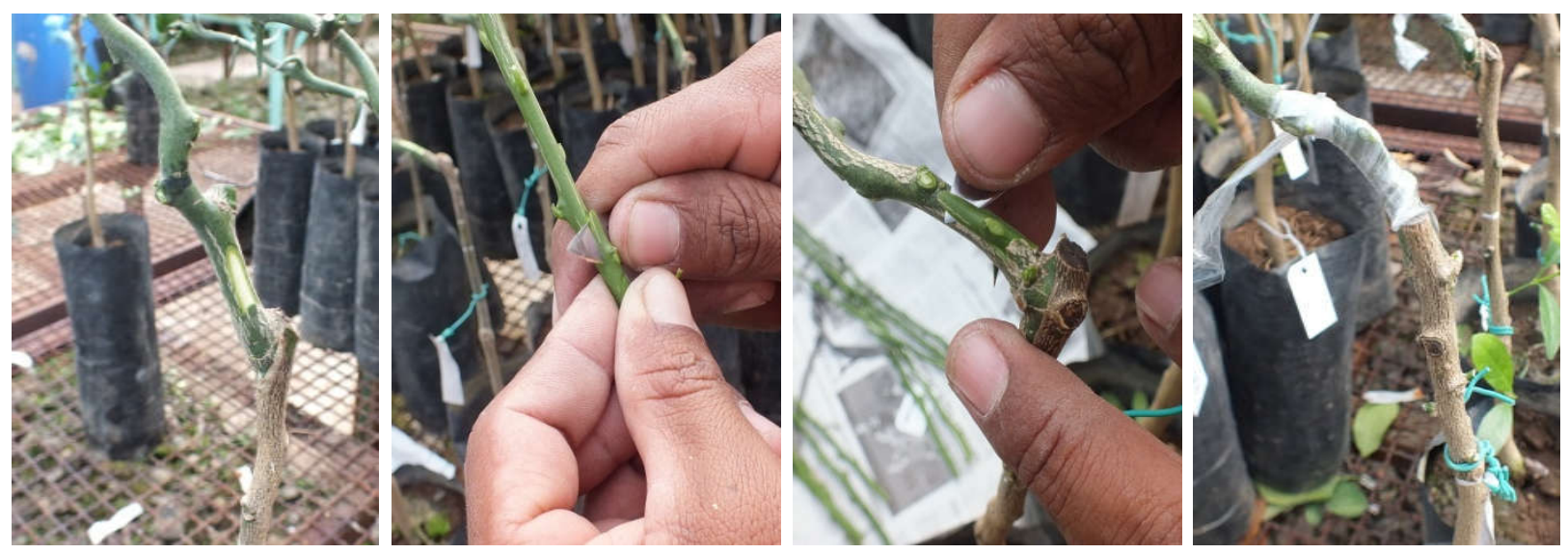

Figure 1 - Grafting process on interstock

Variables of the observations. Observations were conducted to find out the percentage of successful grafting ( 6 week after grafting), the percentage of growing grafting (at final observation), bud break period (6 week after grafting), shoots height (per two-month), interstock diameter (per two-month), shoot diameter (per two-month , and the number of leaves (per two-month).

Data analysis. Data were analyzed using analysis of variance ( $F$ test) at $5 \%$ level to see if there was any significant effect ( $F$ count> $F$ table $5 \%$ ), followed by DMRT at $5 \%$ level.

\section{RESULTS AND DISCUSSION}

The percentage of successful grafting and growing grafting. The results of the observations and measurement on the success of grafting and growing grafting are presented in Table 1. Successful grafting in all treatments showed percentage between $37.5 \%-100 \%$. The lowest percentage was found in the treatment 14/V2 (interstock Volkameriana with scion Tangerine cv. Pontianak) at $37.5 \%$. The response of the interstocks toward different scions resulted in different percentage of successful grafting. Seven interstocks was grafted by Mandarin cv. Batu 55 (V1), Tangerine cv. Pontianak (V2) and Lime cv. Nimas (V3) which showed percentage successful grafting percentage of $100 \%$, $71.43 \%$, and $82.14 \%$, in average respectively. This means that Tangerine cv. Pontianak has the lowest response. Observation on the growing grafting showed percentage between $75 \%$ - $100 \%$. Seventeen combined treatment resulted in an average of growing grafting value at $100 \%$, while the other seven treatments resulted percentage values between $75 \%$ and $87.5 \%$.

Bud break period and shoot height. Buds took 24.75 - 38 days to break (Table 2). I0V1 treatment (JC Rootstock/Scion Mandarin cv.Batu 55) took the longest time to break the dormancy in 38 days, which was significantly different from the I1V2 (Interstock Carizzo citrange/Scion Tangerine cV. Pontianak), I4V1 (Interstock Volkameriana/Scion Mandarin cV. Batu 55), I3V3 (Interstock Poncirus trifoliata/Scion Lime cv. Nimas), dan I3V2 (Interstock Poncirus trifoliata/Scion Tangerine cv. Pontianak). The fastest bud break was found in 
treatment I3V2 (Interstock Poncirus trifoliata/Scion Tangerine cv. Pontianak) for about 24.75 days.

Table 1 - Percentage of successful grafting and growing grafting of several interstocks

\begin{tabular}{l|c|c}
\hline \multicolumn{1}{c}{ Treatment } & $\begin{array}{c}\text { Successful } \\
\text { grafting (\%) }\end{array}$ & $\begin{array}{c}\text { Growing } \\
\text { grafting (\%) }\end{array}$ \\
\hline I0V1 (JC Rootstock/Scion Mandarin cv. Batu 55) & 100 & 100 \\
I0V2 (JC Rootstock /Scion Tangerine cv. Pontianak) & 87.5 & 100 \\
I0V3 (JC Rootstock /Scion Lime cv. Nimas) & 75 & 100 \\
I1V1 (Interstock Carizzo citrange / Scion Mandarin cv. Batu 55) & 100 & 100 \\
I1V2 (Interstock Carizzo citrange / Scion Tangerine cv. Pontianak) & 87.5 & 100 \\
I1V3 (Interstock Carizzo citrange / Scion Lime cv. Nimas) & 100 & 100 \\
I2V1 (Interstock Citrumello / Scion Mandarin cv. Batu 55) & 100 & 100 \\
I2V2 (Interstock Citrumello / Scion Tangerine cv. Pontianak) & 87.5 & 100 \\
I2V3 (Interstock Citrumello / Scion Lime cv. Nimas) & 62.5 & 75 \\
I3V1 (Interstock Poncirus trifoliata / Scion Mandarin cv. Batu 55) & 100 & 100 \\
I3V2 (Interstock Poncirus trifoliata / Scion Tangerine cv. Pontianak) & 62.5 & 100 \\
I3V3 (Interstock Poncirus trifoliata / Scion Lime cv. Nimas) & 87.5 & 75 \\
I4V1 (Interstock Volkameriana / Scion Mandarin cv. Batu 55) & 100 & 100 \\
I4V2 (Interstock Volkameriana / Scion Tangerine cv. Pontianak) & 37.5 & 87.5 \\
I4V3 (Interstock Volkameriana / Scion Lime cv. Nimas) & 75 & 100 \\
I5V1 (Interstock Rough lemon / Scion Mandarin cv. Batu 55) & 100 & 75 \\
I5V2 (Interstock Rough lemon / Scion Tangerine cv. Pontianak) & 75 & 87.5 \\
I5V3 (Interstock Rough lemon / Scion Lime cv. Nimas) & 87.5 & 87.5 \\
I6V1 (Interstock Troyer citrange / Scion Mandarin cv. Batu 55) & 100 & 100 \\
I6V2 (Interstock Troyer citrange / Scion Tangerine cv. Pontianak) & 100 & 100 \\
I6V3 (Interstock Troyer citrange / Scion Lime cv. Nimas) & 100 & 87.5 \\
I7V1 (Interstock Kanci / Scion Mandarin cv. Batu 55) & 100 & 100 \\
I7V2 (Interstock Kanci / Scion Tangerine cv. Pontianak) & 50 & 100 \\
I7V3 (Interstock Kanci / Scion Lime cv. Nimas) & 62.5 & 100 \\
\hline
\end{tabular}

Observation on the shoot height resulted to a range value of growth between $25.66 \mathrm{~cm}$ $-52.2 \mathrm{~cm}$ (Table 2). The lowest growth value was found in the treatment I7V2 (Interstock Kanci/Scion Tangerine cv. Pontianak), which was significantly different from I6V3 (Interstock Troyer citrange/Scion Lime cv. Nimas).

Scion and interstock diameter. The result of the observations on the growth of scion and interstock diameter is shown in Table 3. The largest scion diameter was obtained in the treatment I1V3 (Interstock Carizzo citrange / Scion Lime cv. Nimas) at 7.09 mm, which was significantly different from the scion diameter found in the treatment I7V2 (Interstock Kanci I Scion Tangerine cV. Pontianak), about $3.61 \mathrm{~mm}$. The largest diameter of interstock was obtained in the treatment IOV1 (JC Rootstock / Scion Mandarin CV.Batu 55) at $14.81 \mathrm{~cm}$, which was significantly different from the result of treatment I7V3 (Interstock Kanci / Scion Lime cv. Nimas), $7.52 \mathrm{~mm}$.

Number of leaves. The number of leaves observed in this research were around 15.16 - 43.87 (Tabel 4) which highest value was found in the treatment I1V3 (Interstock Carizzo citrange / Scion Lime cv. Nimas) treatment (43.87), while the lowest value was found in the I7V2 (Interstock Kanci / Scion Tangerine cv. Pontianak) treatment (15.16).

The percentage of successful grafting and growing grafting. Interstock treatment in Mandarin cv. Batu 55 (V1), Tangerine cv. Pontianak (V2), and Lime cv. Nimas (V3) showed that each produced an average percentage of successful grafting of $100 \%, 71.43 \%$ and $82.14 \%$ respectively. The success of grafting of Lime cv. Nimas in several interstocks is found higher than the one in the $J C$ (IOV3) at $75 \%$. Based on the result of the experiment in the field, Lime CV. Nimas seed production using JC rootstock showed percentage of successful grafting about 50-70\% (Andayani, 2016, personal communication). This result was considered as the lowest one compared to the percentages of growing grafting of other scions than Lime cv. Nimas which averagely reached greater than $90 \%$. This result indicated that the use of the seven interstocks was able to increase successful grafting on Lime $\mathrm{cV}$. Nimas, especially on interstock Carizzo citrange (I1) and Troyer citrange (I6) which reached perfect percentage of $100 \%$. The opposite phenomena occured in Tangerine cv. Pontianak, 
which showed that being grafted on seven interstocks, it only produced an average percentage of successful grafting about $71.43 \%$, lower than the one of $J C$ (IOV2) ie $87.5 \%$. This means that the use of those interstocks for Tangerine cv. Pontianak tends to decrease the number of successful grafting and inhibits the growth of the plants. In a research using apple, Karlidag et al, (2014) stated that the use of interstock on vigor rootstock of apple would inhibit the growth of the scion, apple cv. Granny smith and Golden delicious.

Table 2 - Bud break period and shoot height of grafted plants in several interstocks

\begin{tabular}{l|c|c}
\hline \multicolumn{1}{c|}{ Treatment } & $\begin{array}{c}\text { Bud break } \\
\text { period (day) }\end{array}$ & $\begin{array}{c}\text { Shoot height } \\
\text { (cm) }\end{array}$ \\
\hline I0V1 (JC Rootstock/Scion Mandarin cv. Batu 55) & $38.00 \mathrm{a}$ & $26.96 \mathrm{~cd}$ \\
I0V2 (JC Rootstock /Scion Tangerine cv. Pontianak) & $32.37 \mathrm{abc}$ & $35.12 \mathrm{abcd}$ \\
I0V3 (JC Rootstock /Scion Lime cv. Nimas) & $33.87 \mathrm{ab}$ & $34.05 \mathrm{abcd}$ \\
I1V1 (Interstock Carizzo citrange / Scion Mandarin cv. Batu 55) & $29.37 \mathrm{abc}$ & $42.41 \mathrm{abcd}$ \\
I1V2 (Interstock Carizzo citrange / Scion Tangerine cv. Pontianak) & $28.25 \mathrm{bc}$ & $42.88 \mathrm{abcd}$ \\
I1V3 (Interstock Carizzo citrange / Scion Lime cv. Nimas) & $31.87 \mathrm{abc}$ & $45.45 \mathrm{abcd}$ \\
I2V1 (Interstock Citrumello / Scion Mandarin cv. Batu 55) & $32.62 \mathrm{abc}$ & $41.82 \mathrm{abcd}$ \\
I2V2 (Interstock Citrumello / Scion Tangerine cv. Pontianak) & $29.75 \mathrm{abc}$ & $41.56 \mathrm{abcd}$ \\
I2V3 (Interstock Citrumello / Scion Lime cv. Nimas) & $34.16 \mathrm{ab}$ & $45.56 \mathrm{abc}$ \\
I3V1 (Interstock Poncirus trifoliata / Scion Mandarin cv. Batu 55) & $30.37 \mathrm{abc}$ & $31.93 \mathrm{bcd}$ \\
I3V2 (Interstock Poncirus trifoliata / Scion Tangerine cv. Pontianak) & $24.75 \mathrm{c}$ & $28.72 \mathrm{~cd}$ \\
I3V3 (Interstock Poncirus trifoliata / Scion Lime cv. Nimas) & $24.83 \mathrm{c}$ & $39.48 \mathrm{abcd}$ \\
I4V1 (Interstock Volkameriana / Scion Mandarin cv. Batu 55) & $28.00 \mathrm{bc}$ & $46.02 \mathrm{abc}$ \\
I4V2 (Interstock Volkameriana / Scion Tangerine cv. Pontianak) & $33.00 \mathrm{abc}$ & $45.35 \mathrm{abcd}$ \\
I4V3 (Interstock Volkameriana / Scion Lime cv. Nimas) & $32.75 \mathrm{abc}$ & $37.71 \mathrm{abcd}$ \\
I5V1 (Interstock Rough lemon / Scion Mandarin cv. Batu 55) & $30.16 \mathrm{abc}$ & $34.88 \mathrm{abcd}$ \\
I5V2 (Interstock Rough lemon / Scion Tangerine cv. Pontianak) & $34.50 \mathrm{ab}$ & $29.70 \mathrm{~cd}$ \\
I5V3 (Interstock Rough lemon / Scion Lime cv. Nimas) & $33.33 \mathrm{abc}$ & $44.56 \mathrm{abcd}$ \\
I6V1 (Interstock Troyer citrange / Scion Mandarin cv. Batu 55) & $31.87 \mathrm{abc}$ & $39.26 \mathrm{abcd}$ \\
I6V2 (Interstock Troyer citrange / Scion Tangerine cv. Pontianak) & $30.50 \mathrm{abc}$ & $46.17 \mathrm{abc}$ \\
I6V3 (Interstock Troyer citrange / Scion Lime cv. Nimas) & $30.12 \mathrm{abc}$ & $52.20 \mathrm{a}$ \\
I7V1 (Interstock Kanci / Scion Mandarin cv. Batu 55) & $34.25 \mathrm{ab}$ & $29.57 \mathrm{~cd}$ \\
I7V2 (Interstock Kanci / Scion Tangerine cv. Pontianak) & $31.33 \mathrm{abc}$ & $25.66 \mathrm{~d}$ \\
I7V3 (Interstock Kanci / Scion Lime cv. Nimas) & $30.00 \mathrm{abc}$ & $50.80 \mathrm{ab}$ \\
\hline
\end{tabular}

Note: mean values followed by the same letters in the same column show insignificantly different result by DMRT at $5 \%$ level.

Table 3 - Scion and interstock diameter of grafted plants in several interstocks

\begin{tabular}{l|c|c}
\hline \multicolumn{1}{c|}{ Treatment } & $\begin{array}{c}\text { Scion } \\
\text { diameter (mm) }\end{array}$ & $\begin{array}{c}\text { Interstock } \\
\text { diameter (mm) }\end{array}$ \\
\hline I0V1 (JC Rootstock/Scion Mandarin cv. Batu 55) & 4.36 def & $14.81 \mathrm{a}$ \\
I0V2 (JC Rootstock /Scion Tangerine cv. Pontianak) & $4.65 \mathrm{bcdef}$ & $11.46 \mathrm{~b}$ \\
I0V3 (JC Rootstock /Scion Lime cv. Nimas) & $4.89 \mathrm{bcdef}$ & $10.99 \mathrm{bc}$ \\
I1V1 (Interstock Carizzo citrange / Scion Mandarin cv. Batu 55) & $5.12 \mathrm{bcdef}$ & $10.96 \mathrm{bc}$ \\
I1V2 (Interstock Carizzo citrange / Scion Tangerine cv. Pontianak) & $4.80 \mathrm{bcdef}$ & $10.86 \mathrm{bc}$ \\
I1V3 (Interstock Carizzo citrange / Scion Lime cv. Nimas) & $7.09 \mathrm{a}$ & $10.71 \mathrm{bc}$ \\
I2V1 (Interstock Citrumello / Scion Mandarin cv. Batu 55) & $5.81 \mathrm{abcd}$ & $10.36 \mathrm{bc}$ \\
I2V2 (Interstock Citrumello / Scion Tangerine cv. Pontianak) & $5.35 \mathrm{bcde}$ & $10.09 \mathrm{bc}$ \\
I2V3 (Interstock Citrumello / Scion Lime cv. Nimas) & $6.22 \mathrm{ab}$ & $9.99 \mathrm{bc}$ \\
I3V1 (Interstock Poncirus trifoliata / Scion Mandarin cv. Batu 55) & $3.88 \mathrm{ef}$ & $9.91 \mathrm{bc}$ \\
I3V2 (Interstock Poncirus trifoliata / Scion Tangerine cv. Pontianak) & $4.89 \mathrm{bcdef}$ & $9.65 \mathrm{bc}$ \\
I3V3 (Interstock Poncirus trifoliata / Scion Lime cv. Nimas) & $5.51 \mathrm{bcde}$ & $9.55 \mathrm{bc}$ \\
I4V1 (Interstock Volkameriana / Scion Mandarin cv. Batu 55) & $6.04 \mathrm{abc}$ & $9.54 \mathrm{bc}$ \\
I4V2 (Interstock Volkameriana / Scion Tangerine cv. Pontianak) & $5.89 \mathrm{abcd}$ & $9.46 \mathrm{bc}$ \\
I4V3 (Interstock Volkameriana / Scion Lime cv. Nimas) & $5.84 \mathrm{abcd}$ & $9.36 \mathrm{bc}$ \\
I5V1 (Interstock Rough lemon / Scion Mandarin cv. Batu 55) & $5.11 \mathrm{bcdef}$ & $9.28 \mathrm{bc}$ \\
I5V2 (Interstock Rough lemon / Scion Tangerine cv. Pontianak) & $4.55 \mathrm{cdef}$ & $9.20 \mathrm{bc}$ \\
I5V3 (Interstock Rough lemon / Scion Lime cv. Nimas) & $5.59 \mathrm{abcd}$ & $9.19 \mathrm{bc}$ \\
I6V1 (Interstock Troyer citrange / Scion Mandarin cv. Batu 55) & $5.12 \mathrm{bcdef}$ & $8.30 \mathrm{bc}$ \\
I6V2 (Interstock Troyer citrange / Scion Tangerine cv. Pontianak) & $5.10 \mathrm{bcdef}$ & $8.28 \mathrm{bc}$ \\
I6V3 (Interstock Troyer citrange / Scion Lime cv. Nimas) & 6.15 abc & $8.19 \mathrm{bc}$ \\
I7V1 (Interstock Kanci / Scion Mandarin cv. Batu 55) & $4.35 \mathrm{def}$ & $8.14 \mathrm{bc}$ \\
I7V2 (Interstock Kanci / Scion Tangerine cv. Pontianak) & $3.61 \mathrm{f}$ & $8.05 \mathrm{bc}$ \\
I7V3 (Interstock Kanci / Scion Lime cv. Nimas) & $5.42 \mathrm{bcde}$ & $7.52 \mathrm{c}$ \\
\hline
\end{tabular}

Note: mean values followed by the same letters in the same column shows insignificant difference of DMRT at $5 \%$ level. 
Table 4 - The number of leaves of grafted plants on several interstocks

\begin{tabular}{l|c}
\hline \multicolumn{1}{c}{ Treatment } & Number of leaves \\
\hline I1V3 (Interstock Carizzo citrange / Scion Lime cv. Nimas) & $43.87 \mathrm{a}$ \\
I3V3 (Interstock Poncirus trifoliata / Scion Lime cv. Nimas) & $36.50 \mathrm{ab}$ \\
I7V3 (Interstock Kanci / Scion Lime cv. Nimas) & $36.12 \mathrm{ab}$ \\
I1V1 (Interstock Carizzo citrange / Scion Mandarin cv.Batu 55) & $34.25 \mathrm{abc}$ \\
I6V3 (Interstock Troyer citrange / Scion Lime cv. Nimas) & $33.87 \mathrm{abc}$ \\
I6V2 (Interstock Troyer citrange / Scion Tangerine cv. Pontianak) & $33.87 \mathrm{abc}$ \\
I1V2 (Interstock Carizzo citrange / Scion Tangerine cv. Pontianak) & $33.25 \mathrm{abc}$ \\
I4V1 (Interstock Volkameriana / Scion Mandarin cv.Batu 55) & $32.25 \mathrm{abcd}$ \\
I2V3 (Interstock Citrumello / Scion Lime cv. Nimas) & $30.66 \mathrm{abcd}$ \\
I2V2 (Interstock Citrumello / Scion Tangerine cv. Pontianak) & $30.12 \mathrm{abcd}$ \\
I0V3 (JC Rootstock / Scion Lime cv. Nimas) & $28.00 \mathrm{abcd}$ \\
I6V1 (Interstock Troyer citrange / Scion Mandarin cv.Batu 55) & $28.00 \mathrm{abcd}$ \\
I5V3 (Interstock Rough lemon / Scion Lime cv. Nimas) & $26.83 \mathrm{bcd}$ \\
I2V1 (Interstock Citrumello / Scion Mandarin cv.Batu 55) & $26.50 \mathrm{bcd}$ \\
I4V3 (Interstock Volkameriana / Scion Lime cv. Nimas) & $25.12 \mathrm{bcd}$ \\
I4V2 (Interstock Volkameriana / Siam Pontianak) & $25.00 \mathrm{bcd}$ \\
I3V2 (Interstock Poncirus trifoliata / Scion Tangerine cv. Pontianak) & $24.62 \mathrm{bcd}$ \\
I3V1 (Interstock Poncirus trifoliata / Scion Mandarin cv.Batu 55) & $23.37 \mathrm{bcd}$ \\
I0V2 (JC Rootstock / Scion Tangerine cv. Pontianak) & $21.62 \mathrm{bcd}$ \\
I5V2 (Interstock Rough lemon / Scion Tangerine cv. Pontianak) & $20.16 \mathrm{bcd}$ \\
I0V1 (JC Rootstock/ Scion Mandarin cv.Batu 55) & $18.25 \mathrm{~cd}$ \\
I5V1 (Interstock Rough lemon / Scion Mandarin cv.Batu 55) & $18.16 \mathrm{~cd}$ \\
I7V1 (Interstock Kanci / Scion Mandarin cv.Batu 55) & $17.37 \mathrm{~cd}$ \\
I7V2 (Interstock Kanci / Scion Tangerine cv. Pontianak) & $15.16 \mathrm{~d}$ \\
\hline
\end{tabular}

Note: mean values followed by the same letters in the same column shows insignificant difference of DMRT at $5 \%$ level.

The percentage of the growing grafting of interstocks at Mandarin cv. Batu 55, Tangerine cV. Pontianak and Lime cV. Nimas reached $94.04 \%$, which means that only $15.96 \%$ of the plants that failed to grow. Growing grafting is characterized by the emergence and development of buds into new shoots from the successful grafting plants. In some cases, successful grafting do not show any further development, which condition is called dormant. Dormancy can be caused by external and internal factors of the plant itself (Sugiyatno and Anggraini, 2014). Dormancy in bud can be "broken" by administering natural or synthetic growth regulators (Trisnawan, 2015).

Bud break period. The obtained data on the bud break period showed significant differences among treatments given. Treatment IOV1 (rootstock JC/ Scion Mandarin cv.Batu 55) takes the longest time period to induce the break of the buds, which is significantly different from the result of the treatment I1V2 (Interstock Carizzo citrange/ Scion Tangerine cv. Pontianak), 14V1 (Interstock Volkameriana / Scion Mandarin cv.Batu 55 ), I3V3 (Interstock Poncirus trifoliata / Scion Lime cv. Nimas), and I3V2 (Interstock Poncirus trifoliata / Scion Tangerine cv. Pontianak). The most rapid treatment to induce bud break is the treatment I3V2 (Interstock Poncirus trifoliata / Scion Tangerine cV. Pontianak). This means that the use interstock encourages the break of buds. Hormonal factors in plants also have effects on the appearance of the buds, especially in relation to the balance between the abscisic and cytokines hormone (Wardaningsih et al, 2004). In durian, the use of younger rootstock is able to stimulate the break of the buds faster (Bansir, 2011).

Shoot height. The results of the observations on the shoot height showed highest shoot length of $52.2 \mathrm{~cm}$ in treatment I6V3 (Interstock Troyer citrange / Scion Lime CV. Nimas), which is significantly different from the result of the treatment 17V2 (Interstock Kanci / Scion Tangerine cv. Pontianak), of around $25.66 \mathrm{~cm}$. The response of shoot growth is varied depending on the interstocks used in the treatment. The results go consistently with the result of a research conducted by Susanto et al, (2010), in which it was stated that the use of different interstocks would affect the shoot growth of pumello cv. Nambangan. The use of interstock Tangerine shows best result in stimulating the shoot growth of Mandarin $\mathrm{CV}$. Batu 55 resulted from top working by grafting (Sugiyatno et al, 2013). Kosihita et al. (2007) stated that the use of dwarf rootstock or interstocks effectively control the growth of fruit trees, while Das et al. (2011) stated that top performance of apple using through chip budding using 
Oregon Spur interstock significantly affected the number and length of branches in the fourth year.

Scion and interstock diameter. The results showed that the use interstock Carizzo citrange gave significantly different results from the use of interstock Kanci on scion diameter, while the use of rootstock $J C$ showed significantly different results from the use of interstock on interstock diameter. These results are contradictory to the result of a research conducted by Susanto et al. (2010) in which it was which stated that the use interstock Citrumello, Troyer, Flying dragon, and Rangpur lime did not affect the growth of scion diameter of pumello cv. Nambangan, but they significantly affected the growth of interstock diameter.

Number of leaves. Treatment of I1V3 (Interstock Carizzo citrange / Scion Lime cv. Nimas) showed highest number of leave (43.87), which was significantly different from the resut of the treatment of I7V2 (Interstock Kanci / Scion Tangerine cV. Pontianak), which showed value of around 15.16. This result is in line with the result of a study found by Sugiyatno et al. (2013) in which it is stated that interstock Tangerine produces the most number of leaves and it is significantly different from the other treatments in top working of Mandarin cv. Batu 55. Another research on the use of interstock on pumello cv. Nambangan showed that interstock affects the number of leaves growing in the plant (Susanto et al, 2010). Research on top working by grafting in apple also showed significant effect on the number of leaves (Das et al, 2011).

\section{CONCLUSION}

Based on the results of this study, it can be concluded that the use of different interstocks is able to stimulate the plant growth of Mandarin cv. Batu 55, Tangerine cv. Pontianak, and Lime cv. Nimas. Interstock Carizzo citrange also has the ability to replace the use of $J C$ rootstock to boost the growth of Lime cv. Nimas.

\section{REFERENCES}

1. Aboutalebi A., Hamed H. 2014. Salinity and Citrus Rootstocks and Interstocks. International Journal of Plant, Animal and Enviromental Sciences vol. 20 (2014) 654-672.

2. Bansir L. 2011, 'Potential Development of Durian (Durio zibethinus L.) Locale: Exploration, Identification, Crosses and Vegetative Propagation', Dissertation, Graduate Program of Brawijaya University, Malang.

3. Das B, Ahmad N, Srivastava KK, and Ranjan P. 2011. 'Top Working Method and Bloom Density of Pollinizers as Productive Determinant for Spur Type Apple (Malus $\mathrm{x}$ domsetica Borkh.) Cultivars', Scientia Horticulturae, vol. 129, pp. 642-48.

4. Hardiyanto, Supriyanto, A, Sugiyatno, A, Setiono dan Mulyanto, H 2010, 'Technical Guidelines for Free Diseas Citrus Seed Production Technology. Indonesian Citrus and Subtropical Fruits Research Institute. 62 p.

5. Izquierdo AG , Riquelme MT , Porras I , and Ferreres F. 2004. "Effect of the Rootstock and Interstock Grafted in Lemon Tree (Citrus limon (L.) Burm.) on the Flavonoid Content of Lemon Juice". J. Agric. Food Chem., 2004, 52 (2), pp 324-331.

6. Karlidag H, Rafet A, and Ahmet E. 2014. Effects of Interstock (M9) Length Grafted onto MM 106 Rootstock on Sylleptic Shoot Formation, Growth and Yield in Some Apple Cultivars. Journal of Agricultutral Sciences 20 (2014) 331-336.

7. Koshita Y, Kunihisa M, Yasuhisa T, Toshikazu A, Hiroshi Y, and Akifumi A. 2007. Selection of Interstocks for Dwarfing Japanese Persimmon (Diospyros kaki Thunb.) Trees. J. Japan. Soc. Hort. Sci. 76 (4): 288-293. 2007.

8. Nunez EE, Filho F de AA, Stuchi MES, Avilés TC and dos Santos-Diasa CT. 2011, 'Performance of Tahiti lime on Twelve Rrootstocks under Irrigated and Non-irrigated Conditions', Scientia Horticulturae, vol.129, pp. 227-231. 
9. Shokrollah H, Abdullah TL, Sijam K, and Abdullah SNA. 2011, "Potensial Use of Selected Citrus Rootstock and Interstock against HLB Disease in Malaysia". J. Crop Protection 30 (2011): 521-525.

10. Supriyanto A dan Setiono. 2006. 'Evaluation the Performance of the Vegetative Growth of 10 Commercial Citrus Varieties in 4 Varieties of Rootstock in Sambas, West Kalimantan '. Proceedings of The National Seminar on Citrus Tropika Indonesia, Horticulture Research and Development Center, Agency for Agricultural Research and Development, p. 212-220.

11. 2008. 'Growth Performance of Tangerine cv Banjar on 11 Varieties Rootstock at Tidal Land '. Proceedings of the National Seminar on Citrus 2007. p. 228-234.

12. Susanto S, Sugeru H dan Minten S. 2010. 'Vegetative and Generative Growth of Pumello cv. Nambangan on Four Types Interstock', J. Hort. Indonesia., Vol.1, no.2, pp. 53-58.

13. Sugiyatno A, Setyobudi L, Maghfoer M.D dan Supriyanto A. 2013. 'Growth Rresponse of Mandarin cv Batu 55 on Some Interstock Through Top Working Methods ' J. Hort., vol. 23, no.4, p. 329-338.

14. Anggraini A. 2014. "Seed dormancy Breaking of Tumpang Longan with Mechanical Treatment". Proceedings of the National Seminar on Tropical Fruits Nusantara II, Horticulture Research and Development Center, Agency for Agricultural Research and Development, pp. 853-860.

15. Trisnawan AS. 2015. "The Effect of Plant Growth Regulator of Bud Dormancy Breaking Through Grafting" Thesis, Faculty of Agriculture, University of Brawijaya, Malang.

16. Wardaningsih DP, Supriyanto A, Suwasono HYB dan Sitawati. 2004. Effect of Cold Storage of Budwood and Rootstock Thinning Treatment on The Grafting Success of Pummelo (Citrus grandis L. Osbeck). Proceedings of the National Citrus Seminar 2004. P. 241-248

17. Yilmaz B., 2014. 'Different Interstock Lenghts Effect on 'Star Ruby' Grapefruit and 'Kutdiken' Lemon for Some Plant Nutrient Elements', Turkish Journal of Agricultural and Natural Sciences, Spesial Issue: 2, 2014: 1460-1463. 